The Agriculturists 16(2):123-130(2018) ISSN 2304-7321 (Online), ISSN 1729-5211 (Print)

A Scientific Journal of Krishi Foundation

Indexed Journal

DOI: http://dx.doi.org/ 10.3329/agric.v16i02.40350

Impact Factor: 0.568 (GIF, 2015)

Short Communication

\title{
Water Pollution in Chandpai Range of the Sundarbans Mangrove Forest of Bangladesh
}

\author{
AKM. Faruk-E-Azam ${ }^{1}$, Md. Anisuzzaman ${ }^{2}$, Muhammad Maniruzzaman ${ }^{1}$, Md. Nizam Uddin ${ }^{1}$ \\ and Abdullah-Al-Zabir ${ }^{1} *$ \\ ${ }^{1}$ Department of Agricultural Chemistry and ${ }^{2}$ Department of Environmental Science, Patuakhali \\ Science and Technology University, Dumki, Patuakhali-8602, Bangladesh \\ *Corresponding author and Email: alzabir361@gmail.com
}

Received: 16 October $2018 \quad$ Accepted: 25 December 2018

\begin{abstract}
The present study was conducted to assess the water quality at Chandpai range in Bagerhat district of the Sundarbans Mangrove Forest of Bangladesh. Seven water samples were collected during July to December 2014. The water were analyzed for $\mathrm{pH}, \mathrm{EC}, \mathrm{P}, \mathrm{K}, \mathrm{S}, \mathrm{Ca}, \mathrm{Mg}, \mathrm{Cu}, \mathrm{Mn}, \mathrm{Zn}, \mathrm{Fe}$ and B. The EC values of rivers and canals water were found higher than that of the ponds. River waters of Chandpai range were detected as neutral to slightly alkaline. Waters from Karamjalkhal (Lake), Pasur river, Nandabala canal and Ismails Chila were found strongly saline (EC, 8-12 $\mathrm{dSm}^{-1}$ ), Bholakhal (lake) was moderately saline (EC, $\left.4-8 \mathrm{dSm}^{-1}\right)$ and Boiddomari and Dashervarani ponds were poorly saline $(\mathrm{EC}<4$ $\mathrm{dSm}^{-1}$ ) in nature. The concentrations of $\mathrm{K}, \mathrm{Ca}, \mathrm{Mg}, \mathrm{S}, \mathrm{Zn}$ and $\mathrm{B}$ were found higher and $\mathrm{P}, \mathrm{Cu}$ and $\mathrm{Mn}$ were lower at higher EC levels. The concentrations of $\mathrm{K}, \mathrm{S}, \mathrm{Cu}$ and $\mathrm{B}$ in most of the rivers exceeded the permissible level for aquaculture.
\end{abstract}

Keywords: Water pollution, mangrove forest.

\section{Introduction}

The Sundarbans region in Bangladesh has the largest productive mangrove in the world. It is rapidly disappearing as a result of the shrimp farming and wood harvesting industries. Extensive uses of the forest resources and indiscriminate felling have resulted in near extinction of some species (Mahmood, 1999). The mangrove ecosystem provides living support to nearly 1.2 million coastal people who are involved in fishing, hunting, collecting honey, wax and timber. The mangrove forest also has a buffer function, protecting the densely settled agricultural areas to the north from the full force of cyclonic storms and tidal waves (Mepham and Petr, 1987). About a fifth of the 20 million people who live in the coastal region of Bangladesh directly depend on the coastal and marine resources for their livelihood.

Sundarbans in both India and Bangladesh have been declared world heritage sites. However, its biodiversity continues to be threatened by a growing human population that not only exerts pressure on its biological resources, but also on 
the fresh water inflows from upstream area. The coastal environment faces pollution from domestic sewage and toxic pollutant from industrial effluents leading to serious impacts on water and sediment quality as well as on biodiversity. Oil exploration in coastal areas is also emerging as a new threat. This important ecosystem has started losing biodiversity because of over exploitation and habitat destruction. Both the Bangladesh government and UNESCO have emphasized the importance of conservation of biodiversity in the Sundarbans (Sattar and Faizuddin, 1998).

Mangrove ecosystems are specific in numerous aspects (e.g. carbon and nutrients cycles, sediment characteristics, tidal conditions) which are expected to affect the speciation, and therefore the bioavailability of contaminants (Bayen, 2012). It not only acts as a sink or transfers the pollutants but also oxidizes the metals present in the sediment by exuding oxygen into the anoxic soil through aerial roots (Scholander et al., 1968). It can also arrest and bioremediation of certain pollutants (like fluoride) in local environment (Akhand et al., 2012). Mangrove wetlands are used for low cost waste disposal site.

Mangroves like other halophytes also decrease their water and osmotic potentials to maintain turgor at higher salinity (Khan et al., 2000). Detailed hydro-chemical research is needed to evaluate the different processes and mechanisms involved in polluting water. The balance between freshwater and salt water in this wetland has been suffering modifications from the tilting of the G-B delta toward the east and rising sea level. Increased anthropogenic influences like withdrawal of river water from the upstream region and increase in organic and inorganic pollutants have further led to deterioration of health of the wetland (Bhattacharya, 2008).

Very few or no study was conducted in Bangladesh on ionic pollution of water in the Sundarbans mangrove forest. Therefore, the study was carried out to assess the water pollution in Chandpai Range of the Sundarbans mangrove forest of Bangladesh.

\section{Materials and Methods}

Three water samples at $1 \mathrm{~km}$ distance from each other were collected from each of the seven rivers at Chandpai range in Bagerhat area of the Sundarbans such as Karamjolkhal (lake), Pasur river (Karamjol), Pond (Boiddomari), Nandabala canal, Bholakhal ( Kalomteji), Ismails chila and Pond (Dasher varani).

The water samples were collected in half liter sterilized PET bottles. These bottles were cleaned with dilute hydrochloric acid and then washed with tap water followed by distilled water. Before water sampling, containers were again rinsed 3-4 times with river water to be sampled. The water samples were collected far from the bank of the water source to avoid the turbidity of water. Then 2-3 drops of nitric acid was added to each bottle to inhibit the precipitation, adsorption by container wall and microbial degradation. The collected samples were filtered through (Whatman, No. 42) filter paper. Then the samples were kept in refrigerator to prevent the growth and development of algae. Thus the samples were made ready for analyses. For the collection of samples method outlined by APHA (2005) was followed.

The $\mathrm{pH}$ and EC were determined following the methods mentioned by Tandon (1995). Calcium and $\mathrm{Mg}$ were determined by complexometric method of titration as mentioned by Chopra and Kanwar (1986). Potassium was determined flame photometrically (APHA, 2005). Spectrophotometric method was followed for the determination of P, S and B (Page et al., 1982). Zinc, $\mathrm{Cu}, \mathrm{Fe}$ and $\mathrm{Mn}$ were determined with the help of AAS following method outlined by APHA (2005). The mean values of 3 replications of samples were used for statistical analyses for each parameter and the statistical analyses were done following methods outlined by Gomez and Gomez (1984). 


\section{Results and Discussion}

\subsection{The pH, EC and ionic constituents of waters at Chandpai area of the Sundarbans in Bagerhat district}

\subsubsection{The $\mathrm{pH}$ and $\mathrm{EC}$ values in water}

The values of $\mathrm{pH}$ and EC varied from 7.0 to 7.9 and 0.59 to $9.93 \mathrm{dSm}^{-1}$, respectively (Figure 1). The highest $\mathrm{pH}$ was found in the water of the pond at Dashervarani and the lowest was in the water of the rivers at Nandobala, Karamjal and Pasur. The highest EC value was found in Nandobala canal and the lowest was in Dashervarani pond. River waters of this area were detected as slightly acidic to alkaline. All the river waters in this area of the Sundarbans contained EC at strongly saline level (EC>8.0 $\mathrm{dSm}^{-1}$ ) and this might be due to the evaporation of river water in the sampling period. Liss et al. (2004) reported that $\mathrm{pH}$ and SO42- concentration increase during dry season and decrease during wet season. In summer season, $\mathrm{S}$ and $\mathrm{P}$ status were increased might be due to fertigation of agricultural fields.

\subsubsection{The status of $\mathrm{K}$ and $\mathrm{Ca}$ in water}

The concentrations of $\mathrm{K}$ and $\mathrm{Ca}$ varied from traces to 23.46 to 96.96 and 19.41 to $36.29 \mathrm{mgL}^{-}$ 1 , respectively (Figure 2). The highest $\mathrm{K}$ was detected in Karamjalkhal at Chandpai and the lowest level was detected in the pond of Biddomari. The highest $\mathrm{Ca}$ was found in Nandobala Canal and the lowest was in the Pond of Dashervarani. Higher concentrations of $\mathrm{K}$ and $\mathrm{Ca}$ were found at lower $\mathrm{EC}$ and lower $\mathrm{K}$ and $\mathrm{Ca}$ were detected at higher EC levels. The $\mathrm{K}$ concentrations in most of the rivers exceeded the permissible level (Meade, 1989) for aquaculture.

\subsubsection{The status of $\mathrm{Mg}$ and $\mathrm{S}$ in water}

The concentrations of $\mathrm{Mg}$ and $\mathrm{S}$ varied from 1.66 to 1.95 and 10.01 to $33.71 \mathrm{mgL}^{-1}$, respectively (Figure 3). The highest level of $\mathrm{Mg}$ was found in Karamjolkhal at $9.2 \mathrm{dSm}^{-1}$ EC level and the lowest was found in Dashervarani pond at $0.59 \mathrm{dSm}^{-1} \mathrm{EC}$ level. The highest $\mathrm{S}$ was observed in Ismails Chila at Vola camp and the lowest was in Bholakhal at Kalomteji. The observations suggested an elevated level of $S$ at lower EC levels. Similar observations were recorded by Taniguchi and Tase (1999).

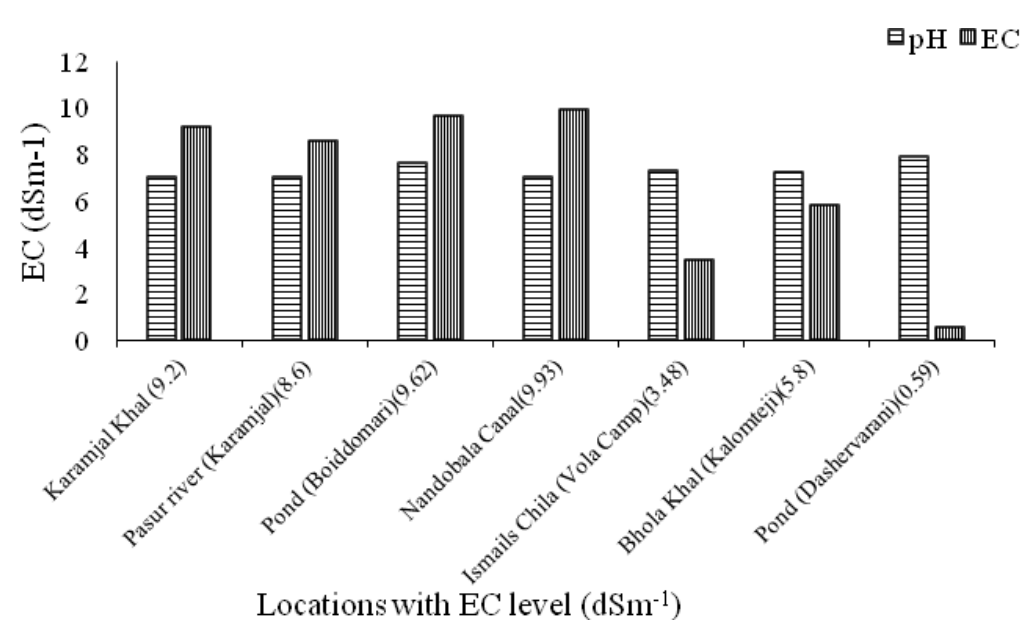

Fig. 1. The values of $\mathrm{pH}$ and $\mathrm{EC}$ at Chandpai area. 


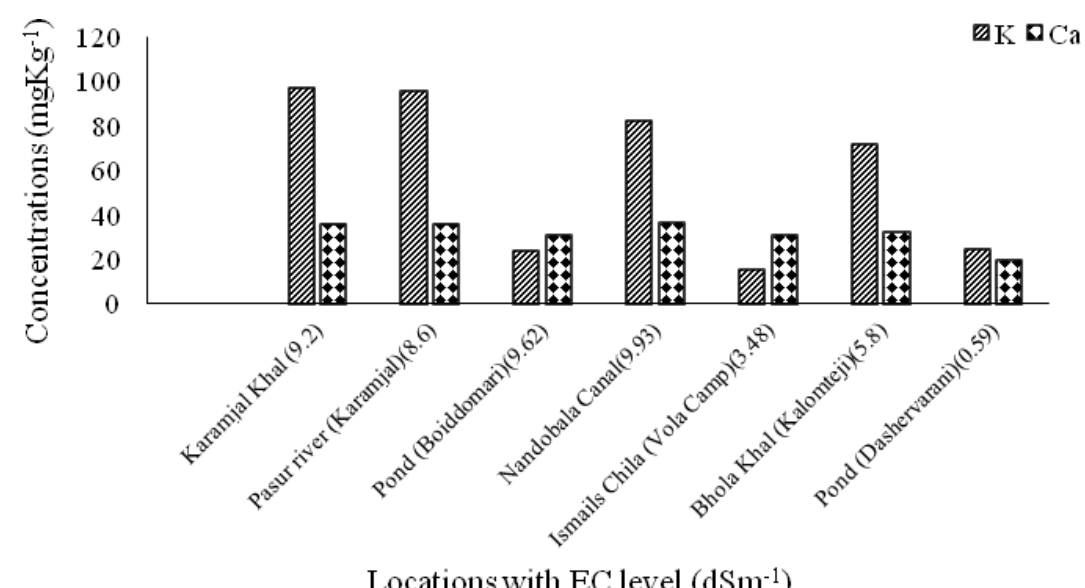

Fig. 2. The concentrations of $\mathrm{K}$ and $\mathrm{Ca}$ at Chandpai area.

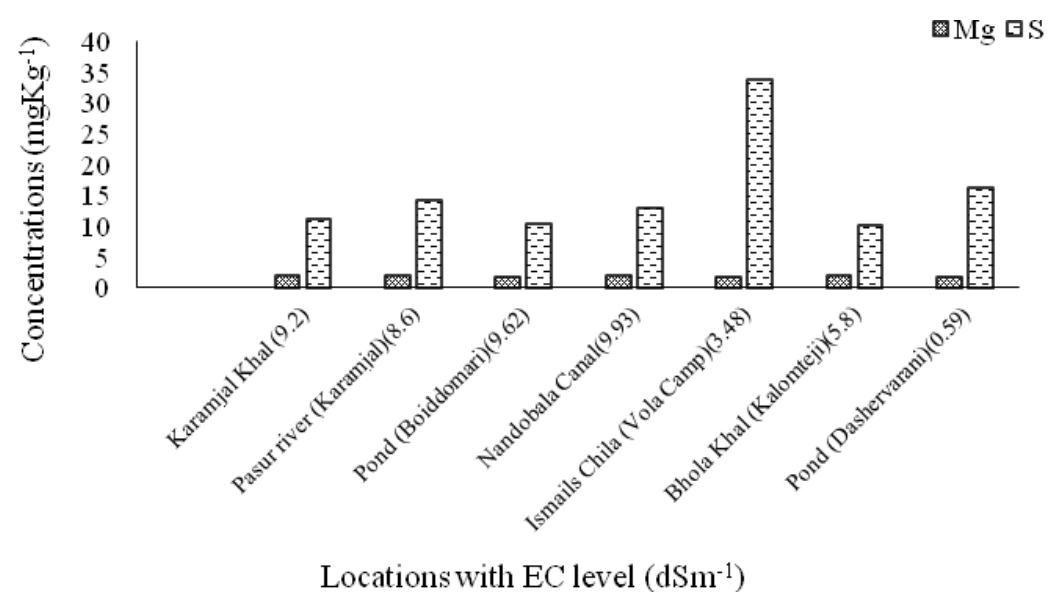

Fig. 3. The concentrations of $\mathrm{Mg}$ and $\mathrm{S}$ at Chandpai area.

\subsubsection{The status of $\mathrm{Cu}$ and $\mathrm{Mn}$ in water}

The concentrations of $\mathrm{Cu}$ and $\mathrm{Mn}$ in water varied from 0.02 to 0.024 and traces to $0.003 \mathrm{mgL}^{-1}$, respectively (Figure 4). The highest amount of both $\mathrm{Cu}$ was found in Ismails Chila and Dashervarani pond at $24.95 \mathrm{dSm}^{-1}$ EC level and the lowest was at Barokeyakhali at 3.48 and 0.59 $\mathrm{dSm}^{-1}$ EC level, respectively. The lowest level Mn was found in Karamjalkhal and Vola camp. The concentrations of $\mathrm{Cu}$ and $\mathrm{Mn}$ were found higher at lower EC levels. The concentration of $\mathrm{Cu}$ was detected at above the permissible level (Meade, 1989) for aquaculture. Similar finding was also reported by Azam et al. (2010). Undisturbed sediments currently situated in the riverbanks contaminates with heavy metals such as $\mathrm{Mn}, \mathrm{Cu}, \mathrm{Pb}$ into the river system during flooding. This release could be markedly enhanced by increased nutrient levels into the river system. 


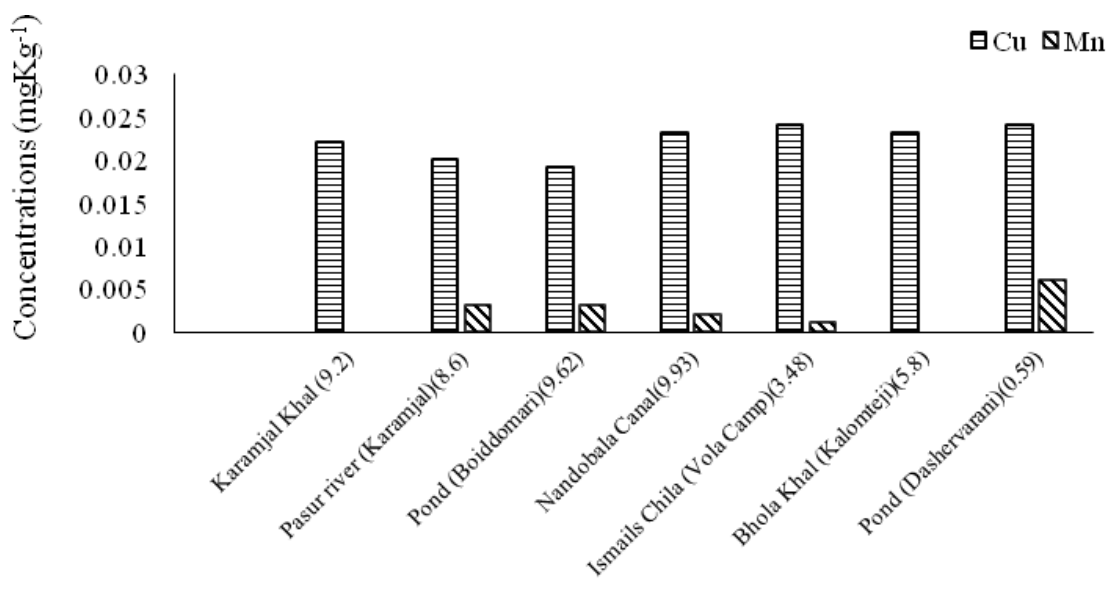

Locations with EC level $\left(\mathrm{dSm}^{-1}\right)$

Fig. 4. The concentrations of $\mathrm{Cu}$ and $\mathrm{Mn}$ at Chandpai area.

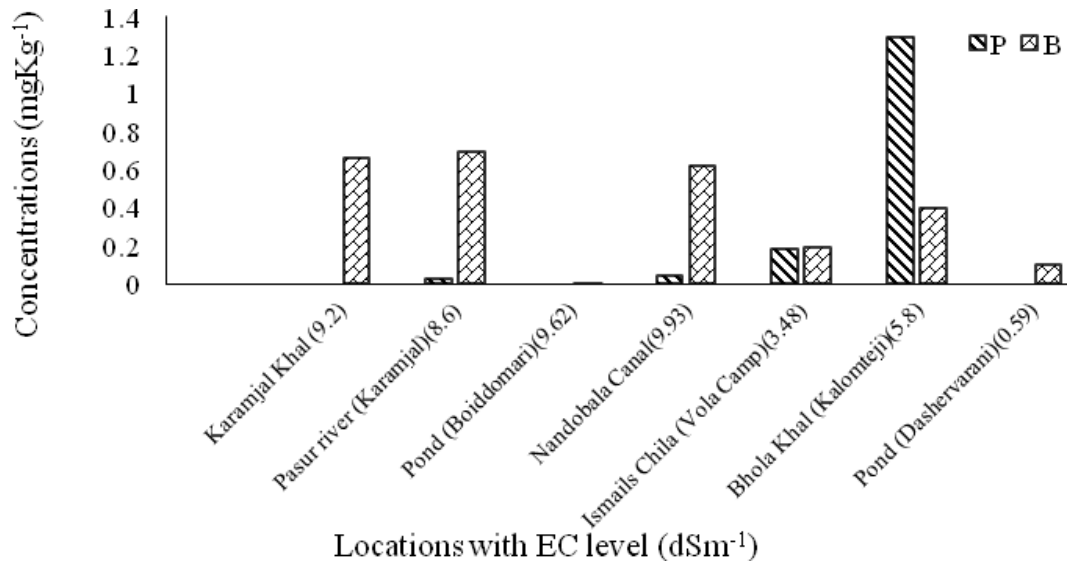

Fig. 5. The concentrations of $\mathrm{P}$ and $\mathrm{B}$ at Chandpai area.

\subsubsection{The status of $P$ and $B$ in Chandpai area}

The concentrations of $\mathrm{P}$ and $\mathrm{B}$ in water varied from traces to 1.289 and $0.1-0.69 \mathrm{mgL}^{-1}$, respectively (Figure 5). The highest $\mathrm{P}$ was detected in BholaKhal at Kalomteji and the lowest level was detected at different locations like Dashervarani pond, Boiddomari pond and Karamjalkhal. The highest level of B was found in Pasur river (Karamjal) at $8.6 \mathrm{dSm}^{-1} \mathrm{EC}$ and lowest was present in Boiddomari Pond at 9.62 $\mathrm{dSm}^{-1}$ EC level. The concentration $B$ was detected at above the permissible level for aquaculture (Meade, 1989). Similar study was conducted by Cheung (2003) who found strongrelation between high $\mathrm{P}$ and $\mathrm{S}$ levels and the discharge of industrial effluents along the river. 
Table 1. pH, EC and ionic constituents of water at different locations at Chandpai range of the Sundarbans in Bagerhat district.

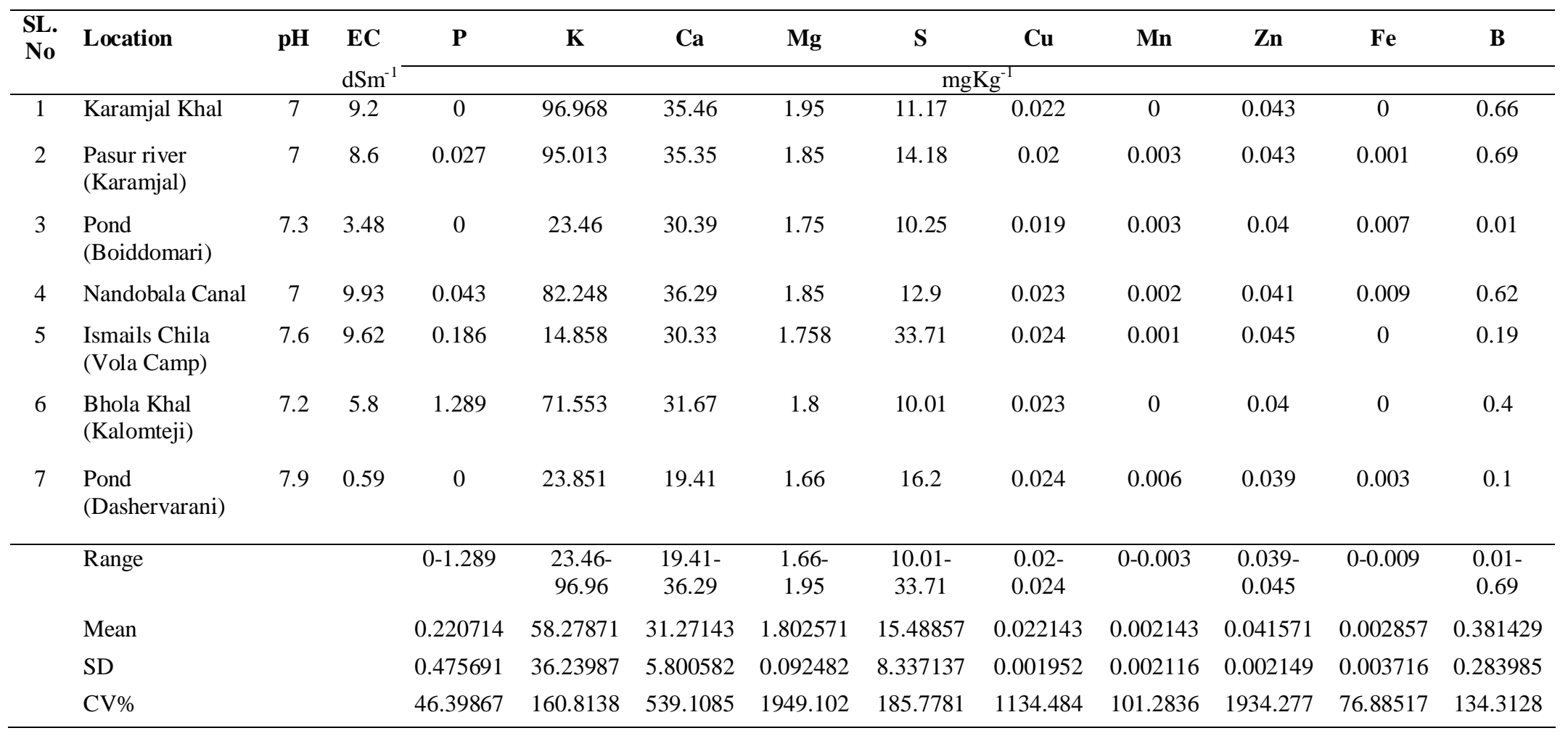

*The value of each parameter indicates the mean value of three replications. 


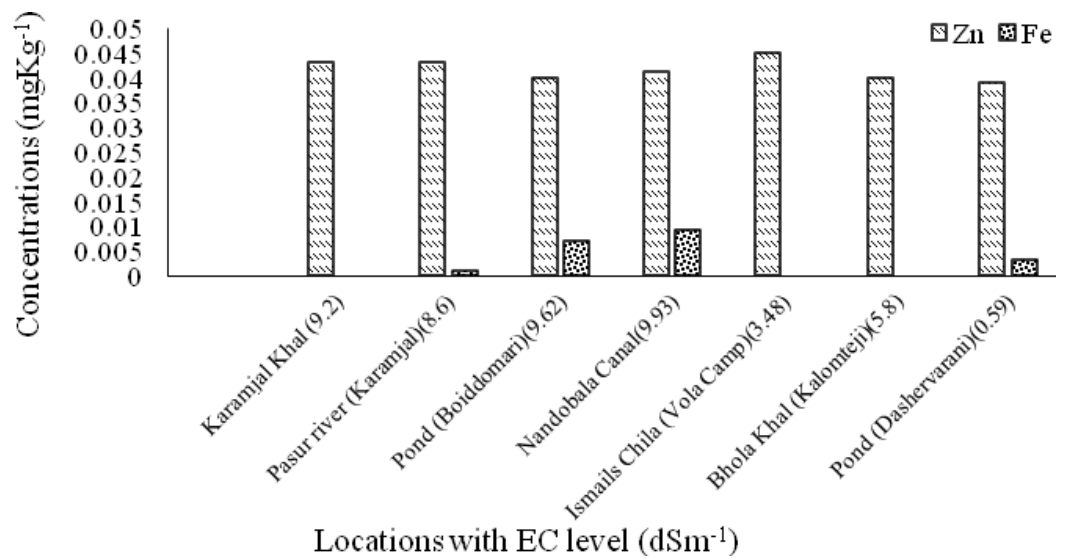

Fig. 6. The concentrations of $\mathrm{Zn}$ and $\mathrm{Fe}$ in Chandpai area.

\subsubsection{The status of $\mathrm{Zn}$ and $\mathrm{Fe}$ in Chandpai area}

The concentrations of $\mathrm{Zn}$ and $\mathrm{Fe}$ in water varied from 0.03 to 0.045 and traces to $0.009 \mathrm{mgL}^{-1}$, respectively (Figure 6). The highest level of $\mathrm{Zn}$ was found in Ismailschila and the lowest was at Dashervarani pond. The highest level of Fe was found in Nandobala and lowest was present in Volakhal, Ismailschila and Karamjalkhal. The concentrations of $\mathrm{Zn}$ and $\mathrm{Fe}$ were found higher at increased EC levels. Force et al. (1998) also conducted a similar study and found that the heavy metal loading of waters in the river system occurs not only as a result of the resuspension of particulate matter. Undisturbed sediments currently situated in the riverbanks contaminate with heavy metals such as $\mathrm{Zn}, \mathrm{Fe}, \mathrm{Mn}, \mathrm{Cu}, \mathrm{Pb}$ into the river system.

\section{Conclusions}

A research was conducted to assess the water quality at selected locations of Chandpai range in Satkhira district of the Sundarbans Mangrove Forest in Bangladesh. Ionic pollution is a great problem in the southern region of Bangladesh and one of the major causes of forest destructions. The water samples were analyzed for $\mathrm{pH}, \mathrm{EC}, \mathrm{P}, \mathrm{K}, \mathrm{Ca}, \mathrm{Mg}, \mathrm{S}, \mathrm{Cu}, \mathrm{Mn}, \mathrm{Zn}, \mathrm{Fe}$ and
B. All the river waters in this area of the Sundarbans contained EC at strongly saline level $\left(\mathrm{EC}>8.0 \mathrm{dSm}^{-1}\right)$. The concentrations of $\mathrm{K}, \mathrm{Cu}$ and $\mathrm{B}$ in most of the rivers detected at above the permissible level for aquaculture.

\section{References}

Akhand A., Chanda S., Dutta S., Hazra, Sanyal P. 2012. "Comparative Study of Heavy Metals in Selected Mangroves of Sundarban Ecosystem", Indian Journal of Environmental Biology, 33(6):10451049.

APHA (American Public Health Association). 2005. Standard Methods for the Examination of Water and Wastewater. $21^{\text {th }}$ edn., AWWA and WEF. Washington, USA, 1-30 40-175 pp.

Azam AKMF., Zaman MW. 2010. Water quality assessment after sudden change of color at the Sundarbans mangrove forest. SAARC Journal of Agriculture, 8(2):76-86.

Bayen S. 2012. Occurrence, Bioavailability and Toxic Effects of Trace Metals and Organic Contaminants in Mangrove Ecosystems: A Review. Environment International, 48:84-101. 
Bhattacharya A. 2008. The morphodynamic setting and substrate behavior of the Sunderban mangrove wetland of India. Sarovar Sourabh, 4(2):2 - 9.

Cheung KC., Poon BHT., Lan CY., Wong MH. 2003. Assessment of metal and nutrient concentrations in river water and sediment collected from the cities in the Pearl River Delta, South China. Chemosphere, 2(9):1431-1440.

Chopra SL., Kanwar JS. 1991. Analytical Agricultural Chemistry. $4^{\text {th }}$ edn., Kalyani Publishers, Ludiana, New Deihi.

Force MJ., Fendorf SE., Li GC., Schneider GM., Rosenzweig RF. 1998. A laboratory evaluation of trace element mobility from flooding and nutrient loading of Coeur d'Alene River sediments. Journal of Environmental Quality, 27(2):318-328.

Gomez KA., Gomez AA. 1984. Statistical Procedures for Agricultural Research. $2^{\text {nd }}$ end., A Wiley Inter-Science Publication, New York, 28-443 pp.

Khan MA., Gul B., Weber DJ. 2000. Germination responses of Salicorniarubra to temperature and salinity. Journal of Arid Environment, 45:207-214.

Liss B. 2004. Aluminum chemistry in soil water, ground water and surface water in an acid sulfate soil area in southern Vietnam. Minor Field Studies International Office, Swedish University of Agricultural Science, 261: 11

Mahmood H., Saberi O., Jaspar, Sidik B., Lim MT. 1999. Distribution of copper in the Sepang mangrove reserve forest environment, Malaysia. Forestry and
Wood Technology Discipline, School of Life Science, Khulna University, Khulna 9100. Bangladesh Journal of Tropical Forest Science, 13(1):130-139.

Meade JW. 1989. Aquaculture Management. Van Nostrand Reinhold (AVI book), New York, USA.

Mepham RH., Petr T. 1987. Papers contributed to the Workshop on Strategies for the management of Fisheries and aquaculture in Mangrove Ecosystems and Country Status reports on inland fisheries presented at the Third Session of the IndoPacific Fishery Commission Working Party of Experts on Inland Fisheries, 2325 June 1986, Bangkok. FAO Fish. Rep., 370 (Suppl.), 248 p.

Sattar MA., Faizuddin M. 1998. Biodiversity of Sundarban mangrove forest of Bangladesh and its conservation. Bangladesh Journal of Forest Science, 27(2):71-75.

Scholander PF. 1968. How mangroves desalinate seawater. Plant Physiology, 21:251-261.

Tandon HLS. 1995. Methods of analysis of soils, plants, waters, and fertilizers. Fertilizer Development and Consultation Organization, New Delhi.

Taniguchi M., Tase N. 1999. Nutrient discharge by groundwater and rivers into Lake Biwa, Japan. Impact of land use change on nutrient loads from diffuse sources Proceedings of an International Symposium held during IUGG-99, the XXII General Assembly of the International Union of Geodesy and Geophysics, at Birmingham, UK, 18-30 July, 67-73 pp. 